\title{
RECENT DEVELOPMENTS ON MORPHOMETRIC ANALYSIS OF KARST CAVES
}

\author{
NOVI PRISTOPI V MORFOMETRIČNI ANALIZI KRAŠKIH JAM
}

\author{
Leonardo PICCINI ${ }^{1}$
}

\begin{abstract}
UDC 551.442

Leonardo Piccini: Recent developments on morphometric analysis of karst caves

Nowadays, the use of computers and the digital techniques for survey processing easily allows to carry out morphometric analysis of caves and karst systems. Morphometric indices have been proposed by many authors in order to describe the genetic features of some particular types of caves, such as coastal ones, maze caves or isolated voids. Large cave systems can be analyzed through the reconstruction of a 3D model. The digital model can be used to evaluate the role of the structural setting or the evolution stages through the recognizing of particular levels where epi-phreatic passages are more developed. These levels are particularly significant when a lithological or structural control can be excluded. Some morphometric indices, obtained by the ratios of simple dimension parameters of caves, allow the statistical analysis of large databases, collected in the regional speleological inventories, in the attempt to recognize different geomorphic populations of caves. Further studies and a greater number of analysis could allow to use these morphometric indices to distinguish genetic categories of caves and to get a useful instrument for the study of the evolution of karst areas.
\end{abstract}

Keywords: cave, cave survey, cave level, morphometry, speleogenesis.

\section{Izvleček \\ UDK 551.442 \\ Leonardo Piccini: Novi pristopi $v$ morfometrični analizi kraških jam}

Računalniška obdelava jamskih meritev omogoča enostavno morfometrično analizo jam in kraških sistemov. Obstaja vrsta morfometričnih kazalcev, ki opisujejo značilnosti jam razvitih v različnih okoljih, kot na primer obalne jame, labirinte in posamezne izolirane votline. Velike jamske sisteme lahko analiziramo na osnovi njihovega 3D modela. Digitalni model omogoča enostavno določitev epifreatičnih nivojev in ovrednotenje pomena strukturnih elementov $\mathrm{v}$ različnih fazah speleogeneze. Ti nivoji so še posebej pomembni, če lahko izključimo pomen strukture ali litologije. Nekatere morfometrične kazalce, kot so razmerja med določenimi dimenzijami, lahko uporabimo na celotnih katastrskih bazah in na ta način iščemo skupne karakteristike skupin znotraj populacije jam. Nadaljnje študije in analize bodo omogočile uporabo teh kazalcev pri interpretaciji razvoja določenega kraškega območja.

Ključne besede: jama, jamski načrt, jamski nivo, morfometrija, speleogeneza.

\section{INTRODUCTION}

Morphometry has been proposed several times as the most important tool to obtain a quantitative analysis of landscape features (e.g., Ewans 1972). For instance, several methods have been proposed for the quantification of drainage network features (e.g., Strahler 1957) or slope shape (e.g., Strahler 1952; Ohmori 1993) through the analysis of topographic maps.

\footnotetext{
${ }^{1}$ Earth Science Department - Via La Pira, 4 - 50121 - Firenze, Italy, e-mail: leonardo.piccini@unifi.it

Received/Prejeto: 9.9.2010
} 
Before the use of computers and vector-maps, these procedures required an extensive handwork and were heavily influenced by the scale factor and the accuracy of the map and by the personal interpretation of the cartographer. The present possibility to use digital elevation models (DEM), derived from aerial photos or radar remote sensing, allows to use automatic procedures and reduces the subjectivity of morphometric investigation by means of a statistical analysis of the results. For sure, morphometry is carrying geomorphology out of "qualitative" sciences and allows a more objective comparison and interpretation of landforms.

But, what about caves? Is it realistic to think using a morphometric approach for cave studies?

A cave is usually described as a natural cavity, which can be accessed by humans. Commonly a minimum length of $5-10 \mathrm{~m}$ is requested to include a cave into a regional inventory.

Curl $(1964,1966)$ suggested the term "proper cave" to indicate a void that is large enough for humans to enter, and "proper entrance" for an entrance naturally passable by persons. The fact that almost all known caves are proper caves with proper entrances is an obvious but important concept and cannot be neglected, because these definitions are evidently anthropocentric and arbitrary and they have no scientific sense (White 1988). This obvious consideration lead us to state that any attempt to describe caves, from a morphological point of view, needs a clear definition of what we mean with the term "cave" and of the scale factor of description.

The distribution of karst cave lengths appears to approximate a power law, when caves without entrances (non-proper caves) are included in the distribution (Curl 1964). The implication of a power law distribution is that the length of caves is a scale-invariant parameter and so is closely associated with self-similar fractals (Curl 1986). This property also offers the possibility to estimate the number, length or volume of non-proper caves in a region (Curl 1966) or surrounding non-proper caves connected to an explored cave (Finnesand \& Curl 2009).

As a matter of fact, the part of a cave that we can directly investigate is always a minimal part of the whole underground network of voids, because some kind of obstruction usually stops the exploration. For this reason, only a small part of explored caves can be considered as well surveyed; and only in these cases we can perform a reliable morphometric analysis of a single system. More generally, we can take into account a large population of caves of a determined karst area, to get a statistically significant description of the cave development.

We have also to remind that different processes can form caves and, consequently, this generic word collects extremely different "morphological" objects, which sometime have in common the only characteristic to be dark inside. Anyway, most of the caves are due to dissolution processes and develops in soluble rocks such as limestone, dolostone or gypsum (karst caves). These caves are usually a complex and three-dimensional system of interconnected voids whose function is, or has been, to move infiltration water to one or more springs (Palmer 1991; Ford \& Williams 2007; De Waele \& Piccini 2008). Hypogenic caves have a different origin and are due to deep groundwater rising up under artesian or convective flow conditions (Klimchouk 2007).

This paper summarizes some of the morphometric approaches for karst cave description, which can be useful to depict a single cave system from a structural and/ or speleogenetic point of view and, finally, to recognize different morphological kinds or generations of caves.

\section{DIGITAL PROCESSING OF CAVE SURVEYS}

Cave mapping is usually performed using a cave compass (Suunto type), a clinometer and a tape meter or, more recently, a laser meter. The use of laser meters allows an easy and quick measuring of cross sections of conduits at each survey station.

Survey data can be processed with a specific software, which consents to build a 3D model of the cave and to automatically extract some of the most usual dimensional parameters such as: total length, horizontal length, depth, floor area, volume, volume density (cave porosity) and so on. Unfortunately, most of the caves explored in the past do not have a digital survey, but some simple procedures allow to get at least the area and the volume of a cave by analyzing the hardcopy of map and profiles.

Cave maps can be scanned at an appropriate definition and then digitized, obtaining one or more vector polygons of the cave wall perimeter, whose areas can be measured using a technical-drawing software. Raster images can be analyzed using an image-processing software (e.g. the free software "Image J"), which can also be used to measure areas of polygons and longitudinal or transverse axis.

When caves have a very complex pattern, the digitizing is a very long procedure and is difficult to be 
achieved if we do not have a good map of the cave. In these cases, an approximate measure of the cave area can be obtained scanning a full black map of the cave, or painting the cave drawn with black using the "fill" tool of a common drawing software. For usual metric scales, a
254 dpi definition is reliable to get directly the area coverage of a single pixel in the raster image. Afterwards, many image-processing softwares allow to count the black pixels, obtaining the area of the drawn cave.

\section{CAVE-MAP DERIVED MORPHOMETRY}

The cave maps measuring offers the possibility to obtain some useful morphometric indices.

Klimchouk (2003) suggests some parameters to compare caves by the total area of passages and chambers and by the whole volume of voids. Such parameters are not usually described in cave inventories, so this kind of analysis requires a specific elaboration of the cave surveys. The cave area can be measured from maps, whereas the volume can be obtained by summing up volumes of individual segments, determined from original measurements of length, width, and height at every survey station. Cave volume is difficult to evaluate without a $3 \mathrm{D}$ processing of a cave plot. A rough estimation can be obtained from the area multiplied by the mean height, which can be estimated on a longitudinal profile of the cave.

The "cave-field" is the area of a polygon surrounding the plan map and provides a measure of the surface occupied by a cave. The method, by which the cave field is calculated, is of great importance (Fig. 1). The simplest way is to consider the smallest rectangle that includes the entire cave plan. Finnesand \& Curl (2009) define the "Minimum Horizontal Polygon Field" such that where

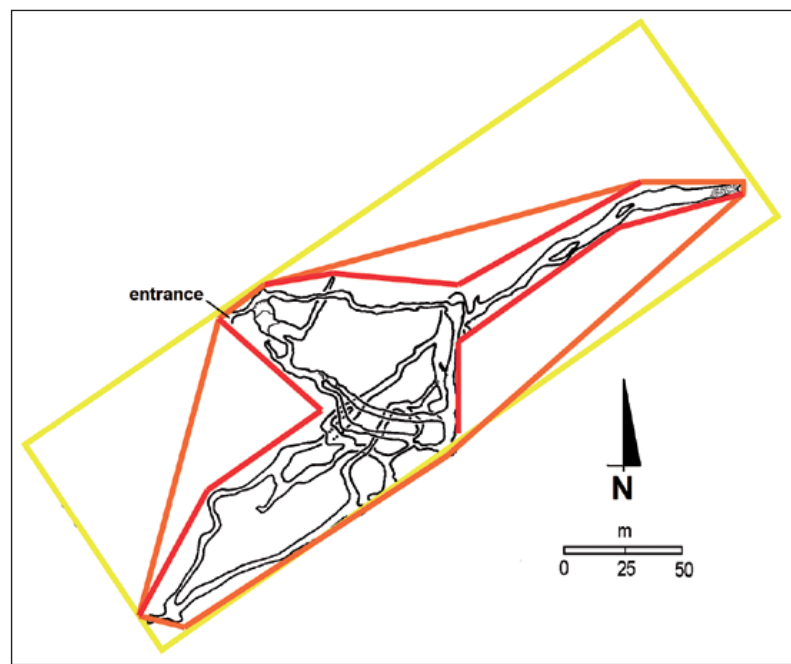

Fig. 1: Three different ways to trace the "cave field" from the plan view: yellow line) minimum rectangle; orange line) minimum convex polygon; red line) best fitting circumscribing polygon. any line segment of the polygon is as long as possible and does not cross a shot. Klimchouk (2003) uses complex polygons in order to closely embrace the cave. Another possibility is to consider the smallest convex polygon obtained jointing the most external points of the cave on the map. Anyway, the polygon can be drawn in many ways and the cave-field may usually range within a $30 \%$.

Klimchouk (2003) indicates four indices as the most indicative to characterize the amplitude of karst development.

Areal Coverage - is the area of the cave itself over the area of the cave field, expressed as a percentage.

Specific Volume - volume/length ratio, it characterizes an average size of cave passage in the cave system.

Passage Network Density - is the ratio of the length over the area of the cave-field.

Cave Porosity - is the volume of the cave divided by the volume of the "cave block", obtained by multiplying the area of the cave-field by the vertical range, expressed as a percentage.

These parameters are useful to characterize maze caves, but do not seem to be reliable for complex alpine caves with a significant vertical development.

The map analysis has been used successfully for particular type of caves, such as coastal caves (Roth 2004; Roth et al. 2006) or isolated voids (Frumkin \& Fischhendler 2005). Mylroie \& Mylroie (2007) describe a method proposed by Roth (2004) for the morphometric analysis of sea and flank-margin caves (Mylroie \& Carew 1990). Cave maps are measured on a digital image to determine the following dimensional parameters: cave Area (A), Perimeter (P), Entrance Width (EW), Interior Width (IW), Short axis (S), Long axis (L) and Box area $(=\mathrm{S} \times \mathrm{L})$. The proposed morphometric indices are:

$\boldsymbol{A} / \boldsymbol{P}$ - Area over Perimeter;

$S / L$ - Short axis over the Long axis, of the major void on cave plan;

$E W / I W$ - Entrance Width over the greatest Interior Width;

Box fill - percentage calculated dividing the Area of the cave by the area of the minimum rectangular area containing the cave plan. 
These indices show that coastal caves of different origins, such as flank margin, sea, and tafoni caves, can be quantitatively differentiated. The Area vs. $\boldsymbol{A} / \boldsymbol{P}$ ratio graph provides the best evaluation of the morphological difference between these three kinds of cave. Area vs. $\boldsymbol{E W} / \mathbf{I} \boldsymbol{W}$ demonstrate that sea caves and tafoni have an $E W / I W$ around one, whereas the flank margin caves have an $\boldsymbol{E W} / \mathbf{I} \boldsymbol{W}$ ratio usually less than one (Mylroie \& Mylroie 2007). This difference reflects the origin of sea caves and tafoni, which is from the outside inward, and whose entrance width is similar to interior width. Conversely, the flank margin caves are due to the intersection of isolated dissolution chambers by surface erosion, and translates into a $\boldsymbol{E} \boldsymbol{W} / \mathbf{I} \boldsymbol{W}$ ratio $<1$.

Frumkin \& Fischhendler (2005) suggest using the following two-dimensional parameters to describe mainly horizontal caves.
Cave Area - horizontal plan area of the cave;

Areal Coverage - cave area divide by the minimum rectangular area circumscribing the cave;

Mean Width - cave area divided by the plan length;

Length/Width ratio $(\boldsymbol{L} / W)$ - cave plan straight length (Long axis) divided by mean width;

Passage Density - cave length divided by the minimum rectangular area circumscribing the cave.

The authors use these parameters to divide chamber caves from maze ones. The limit has been arbitrary fixed for a $L / W$ ratio $>20$, even if typical chamber caves have a $L / W<3$.

All these kinds of parameters are not reliable to describe large integrated conduit system, which often have a significant vertical development. In short this kind of approach seems to be reliable only for small-medium caves with a simple pattern.

\section{MORPHOMETRY AND GEOLOGICAL STRUCTURE}

Geological structure defines the network of lithological discontinuities (bedding planes, joints and faults), which are the potential ways for underground water flow (Dreybrodt \& Siemers 2000; Klimchouk \& Ford 2000). Some authors (e.g., Eraso \& Herrero 1986) have predicted the pattern of cave systems through a structural analysis of rock masses, but, actually, only a stochastic model can be obtained from this kind of approach.

The analysis of the plan distribution (two-dimensional) of cave passage directions, easily allows to recognize the role of vertical discontinuities, such as fractures or faults, through the frequency distribution of the survey shot directions. Results are usually showed as rose or star diagrams, which can be compared with the mean directions of tectonic lineaments (Fig. 2). Many studies show a clear correlation between cave passages and the fracture/fault network (e.g., Deike 1969; Piccini 1992; Hauselmann et al. 1999).

The study of the role of bedding planes, in respect of the distribution of conduits, requires a three dimensional analysis of cave patterns. A promising approach is that of Filipponi et al. (2009) that analyze the 3D geometry of complex cave systems in respect to the geological setting as well as to the hydrogeological boundary conditions. The proposed method allows to get a statistical evidence of the "inception horizon" concept (Lowe 2000; Plan et al. 2009). In a few words, the development of karst conduits under initial phreatic conditions occurs mainly along a restricted number of layers of a rock succession, that are particularly prone for dissolution because of physical or chemical characteristics.

The method requests a detailed geological 3D model, which is analyzed through a software tool that provides the relationships among the conduit network

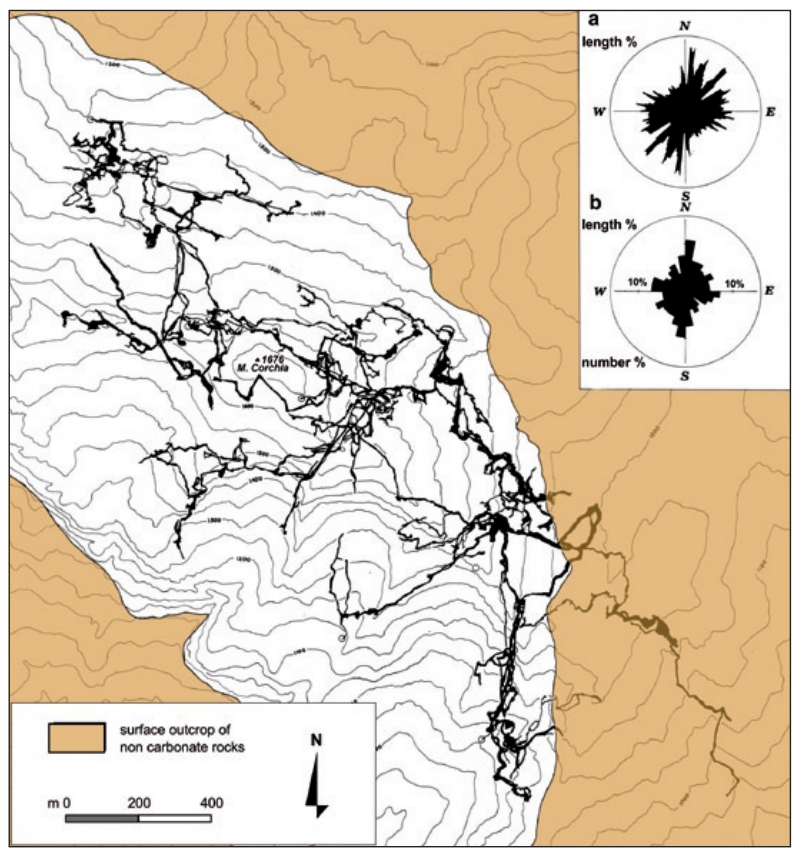

Fig. 2: Plan view of Corchia Cave System (Alpi Apuane, Tuscany): a) star graphs of cave passage directions (length \%, $1^{\circ}$ classes); b) rose diagram of length-\% (upper semicircle) and of number-\% of cave passages (lower semicircle) (after: Piccini 1992, modified). 
geometry, the geological settings and the hydrogeological context. Data needed for this analysis are descriptions in $3 \mathrm{D}$, as complete and precise as possible, of the geology (faults and beddings orientation) and of the cave (survey data). The cave passage distribution is calculated as the distances of every segment from a reference layer, usually the base of the limestone sequence.
This kind of analysis is reliable mainly in phreatic multi-phase cave complexes developed in gently dipping bedded limestone (Plan et al. 2009), which were formed under low hydraulic gradients, whereas it is more difficult to be used in complex geological settings with faulted rock and highly dipping limestone.

\section{MORPHOMETRY AND CAVE LEVELS}

Most of the longest and deepest caves in the world are multistage caves, developed in a very long time (commonly some million years) and often under variable hydrodynamic conditions. Complex caves usually display a multilevel pattern because they record a tectonic and/or a climate-induced step evolution, even if a direct climatic control on vertical distribution of passages can be excluded in most of the cases.

Cave levels are one of the morphological features that have been proposed many times as a consistent indicator of karst evolution phases (see Palmer 1987, and references therein).

The occurrence of almost horizontal levels of cave passages is often due to hydrological factors. So, the individuation of elevation ranges where is a preferential development of epiphreatic or phreatic passages, is particularly significant and their meaning can be compared to that of river terraces (Coltorti 1981; Williams 1982).

Cave levels can be recognized through a statistical analysis of the altimetric distribution of cave passages. The simplest analysis concerns the counting of cave passages included in defined elevation classes (Fig. 3). The obtained frequency graph reflects the vertical distribu- tion of cave passages and furnishes a first tool to distinguish different steps of karst evolution, usually referred to persisting base levels.

A further and more accurate analysis concerns the altimetric distribution of phreatic and epiphreatic passages. Cave level can be correctly interpreted only when an accurate morphologic and structural analysis is performed in order to exclude a litho-structural control as in the case of inception horizons (Filipponi et al. 2009). In several cases, more karstifiable horizons or low permeable layers can guide the development of sub-horizontal streamways or canyons in the vadose zone. In this case the cave levels do not necessarily indicate a base level. For this reason, applying the cave passage distribution analysis can be difficult in those situations characterized by a horizontal layer setting.

When we want to correlate cave levels at different places, we have to take into account the role of vertical movements due to dip-slip faults, which could be acting after or during the development of karst. A correct interpretation of cave levels as indicators of vertical movements can be achieved only through a careful analysis of hypogean morphology and in particular through the individuation of epiphreatic passages, which indicate the position of the water table and that can be properly correlated to old base levels (Piccini 1994, 1998; Haüselmann et al., 2003).

Fig. 3: Altimetric distribution of phreatic and epi-phreatic passages in the Alpi Apuane karst: dark green Corchia Cave system; light green other Apuane caves. 


\section{PATTERN MORPHOMETRIC INDICES}

All the morphometric analyses previously discussed need a long work of digitizing the cave maps or the possibility to obtain a 3D model from survey data. This kind of approach is helpful and promising but, unfortunately, only a few caves in the world have a digital dataset reliable for 2D and 3D morphometric analysis, while there is a lot of simple dimensional data on regional cave inventories.

The electronic archives of cave data allow the elaboration and the statistical analysis of a large number of caves. In particular, the usual dimensional data can be used to extract some simple morphometric indices, which describe the geometric features of caves (Piccini 2001). While the elaboration of these data is relatively simple, their interpretation needs many attentions and it seems difficult to think that such a morphometric approach alone can provide a significant classification of caves into different morphological kinds.

The first strong objection is again that the part of a cave that we know is usually very limited in respect to the real development of the whole karst system. The knowledge of a cave is always partial and subjective, being due to the actual possibility to be explored and to the capability of cavers. For example, it is reasonable to think

\section{3/MS BUCA DELLE OMBRE

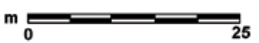

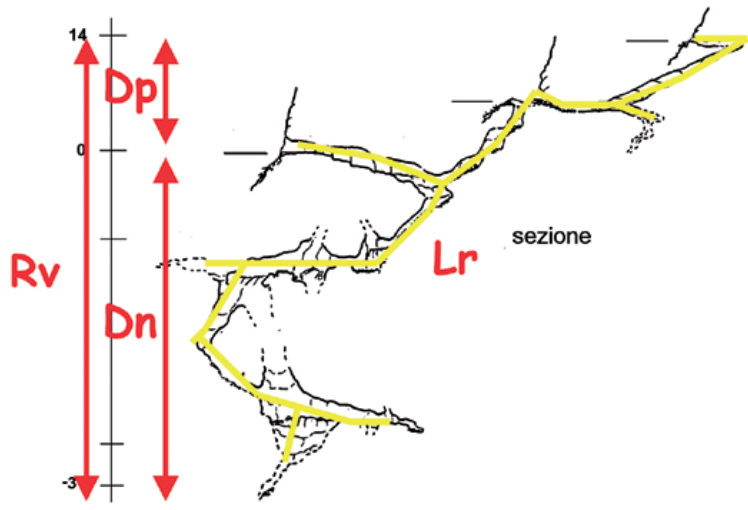

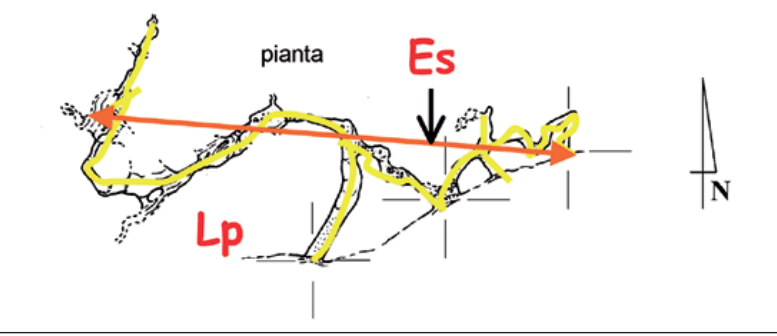

Fig. 4: The dimensional parameters obtained from a cave map. that "different" caves, which open in the same sector of the catchment area of a karst spring, belong to the same karst system and are thus the same "cave" even if there are not connecting passages for humans.

It is a matter of fact that where cavers have been working for a long time and with a particular effort, the explorations have lead to the survey of few but large complexes with several entrances. In other words the results of the application of morphometric indices based on dimensional data always depends on the progress of speleological investigation. Anyway, some kind of analysis, when performed with critical sense and where the deep karst is well known, can provide useful indications to recognize cave morphological types and different generations of caves.

The survey is the usual way the cavers utilize to describe the shape of a cave. Cave surveys are shown as a plan view and as longitudinal or extended profiles, which show the vertical pattern of the cave. The survey data can be summarized in some simple dimensional parameters concerning vertical or horizontal development (Fig. 4). The most used parameters are:

Negative Drop (Dn) - elevation distance from the entrance and the deepest point of the cave.

Positive Drop (Dp) - elevation distance from the entrance and the highest point of the cave really achieved.

Vertical Range (Rv) - sum of Dn and Dp.

Real Length (Lr) - real development of the cave, including all branches and vertical pits. In practice it is the sum of all the survey ties.

Plan Length (Lp) - total length of the plan view of all the cave passages.

Extension (Ex) - horizontal distance of the most far-away points of the cave.

Elevations ranges (Dn, Dp and $\mathrm{Rv}$ ) and extension are well determined parameters, whereas real and plan length ( $\mathrm{Lr}$ and $\mathrm{Lp}$ ) follow a fractal law and depend on the accuracy of the survey or, in other words, on the mean length of survey shots (Curl 1986). The use of a laser distance-meter, for instance, which allows to measure long shots, reduces the "length" of the cave, in respect of what usually happens using a tape meter.

The combination of these dimensional parameters allows to get some simple indices, which show the most important morphometric features of a cave (Fig. 5).

Verticality index $(\mathrm{Vi})=\mathrm{Rv} / \mathrm{Lr}$

It ranges theoretically from 1 to zero. The perfect vertical pits with a small plan length have $V \boldsymbol{i} \sim 1$. The deepest single pits in the world, for instance, have Vi $>0.9$. 


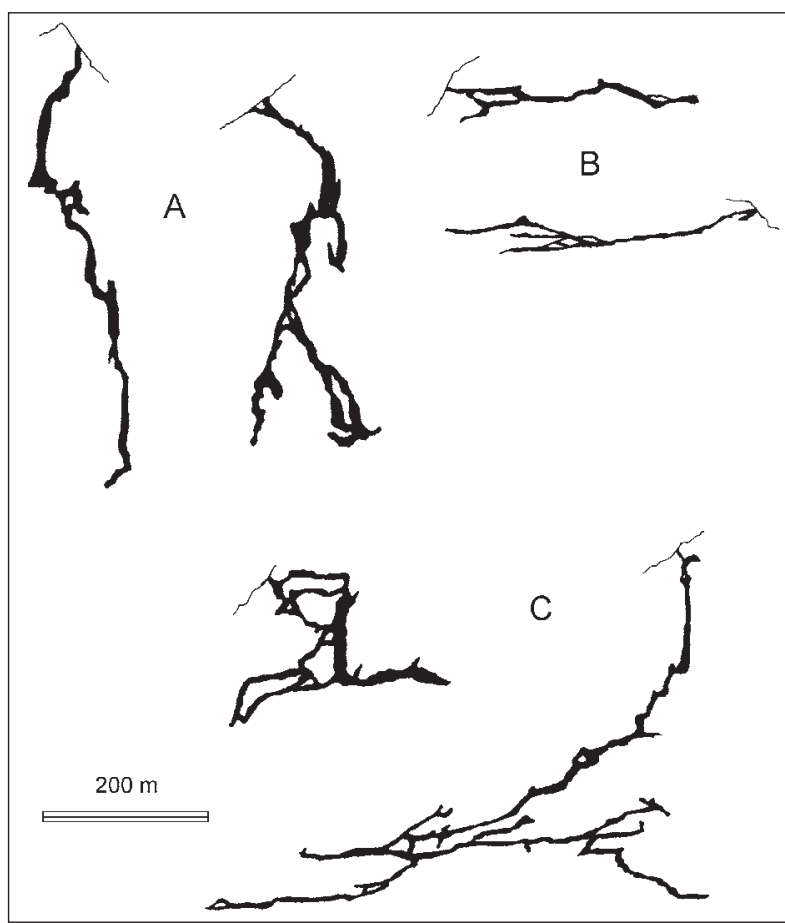

Fig. 5: Examples of medium-size caves with different vertical pattern: A) mainly vertical; B) mainly horizontal; C) complex and multilevel caves.

Many small vertical caves in the infiltration zone of alpine karst have a $\boldsymbol{V i}$ greater than 0.8-0.9 because they are simple pits filled at the bottom with detritus fallen from the entrance. With the increase of depth the $\boldsymbol{V} \boldsymbol{i}$ can be a measure of how close the pits are, in the vertical alpine-type caves, and can be a measure of the effects of structural factors on the pattern of a cave. This index can be successfully applied only on caves of median depth and with no significant branches.

\section{Horizontality index $(\mathrm{Hi})=\mathrm{Lp} / \mathrm{Lr}$}

It theoretically ranges from 1 to zero. Caves with a high $\mathbf{H i}$ are those with an almost perfect horizontal pattern such as the interstratal caves in horizontal bedding setting or water level (piezometric) caves.

Most of the longest caves in the world have a $\mathbf{H i}$ greater than 0.8-0.9 even if their depth is high. For instance, the long caves of Ukrainian gypsum karst have $\boldsymbol{H} \boldsymbol{i} \approx 1$, whereas many of the alpine karst complexes have $H i \approx 0.6-0.7$.

\section{Linearity index $(L i)=\left(E x^{2}-R v^{2}\right)^{1 / 2} / L r$}

It theoretically ranges from 1 to zero and indicates how much a cave has a pattern that fits a straight line, either vertical, inclined or horizontal.

Typical caves with high $\boldsymbol{L i}$ are epidermic interstratal caves with high bedding dip, or "hydrological through caves" characterized by heavy discharges and developed along a line of maximal gradient connecting a sinking stream to the resurgence.

\section{Horizontal complexity index $(\mathrm{Hci})=L p /$ Es}

It theoretically ranges from 1 to $\infty$, but it is usually $<100$. High values, usually greater than 10 , are typical of maze caves. The highest values are those of artesian flow caves (Klimchouk 2003). Median values are typical of large complex with a well-hierarchic pattern of vadose passages connecting downward in to one main collector. Low values are typical of through-caves and small cavities. The giant Ukrainian caves in gypsum have $\mathbf{H c i}>50$, whereas the largest alpine complexes have $\mathbf{H c i}$ ranging from 10 to 20 .

The verticality, horizontality and linearity indices, if compared with field geological data, can help us to understand the different effects of structural features (orientations of discontinuity surfaces) respect to hydrogeological setting (piezometric geometry) in the development of karst caves. The linearity and horizontal complexity indices seem to be the most reliable ones to give indications on the hydrodynamic characteristics of underground flow during speleogenesis. The applicability of such indices depends on the state of knowledge of karst phenomena. It is obvious that an analysis on a small sample of caves is not significant.

In other words we must take into account a representative population of caves that can be filtered to improve the interpretation. In general we should not consider the smallest caves (length $<50 \mathrm{~m}$ ), because their indices can be determined by their pattern and by the kind of surveying (Fig. 6), and large cave complexes, which can be multi-phase systems and should be analyzed separately.

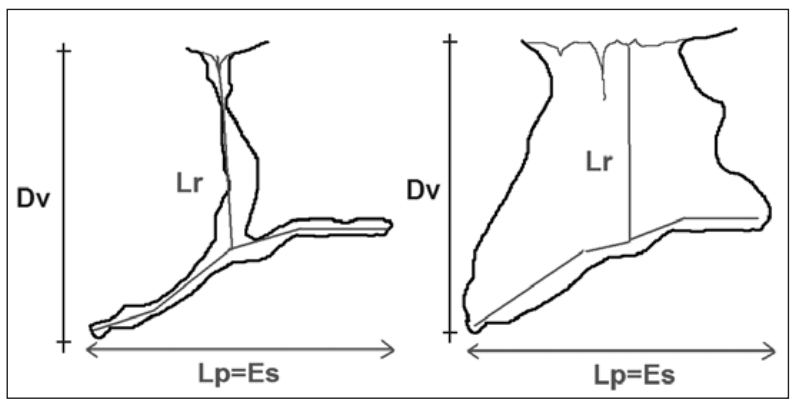

Fig. 6: Caves with different shape having the same dimensional parameters and the same morphometric indices.

The indices can be analyzed by cross correlation with other parameters such as dimension or elevation. The elevation of a cave is referred to the entrance and so it often has no genetic significance since it can be for- 

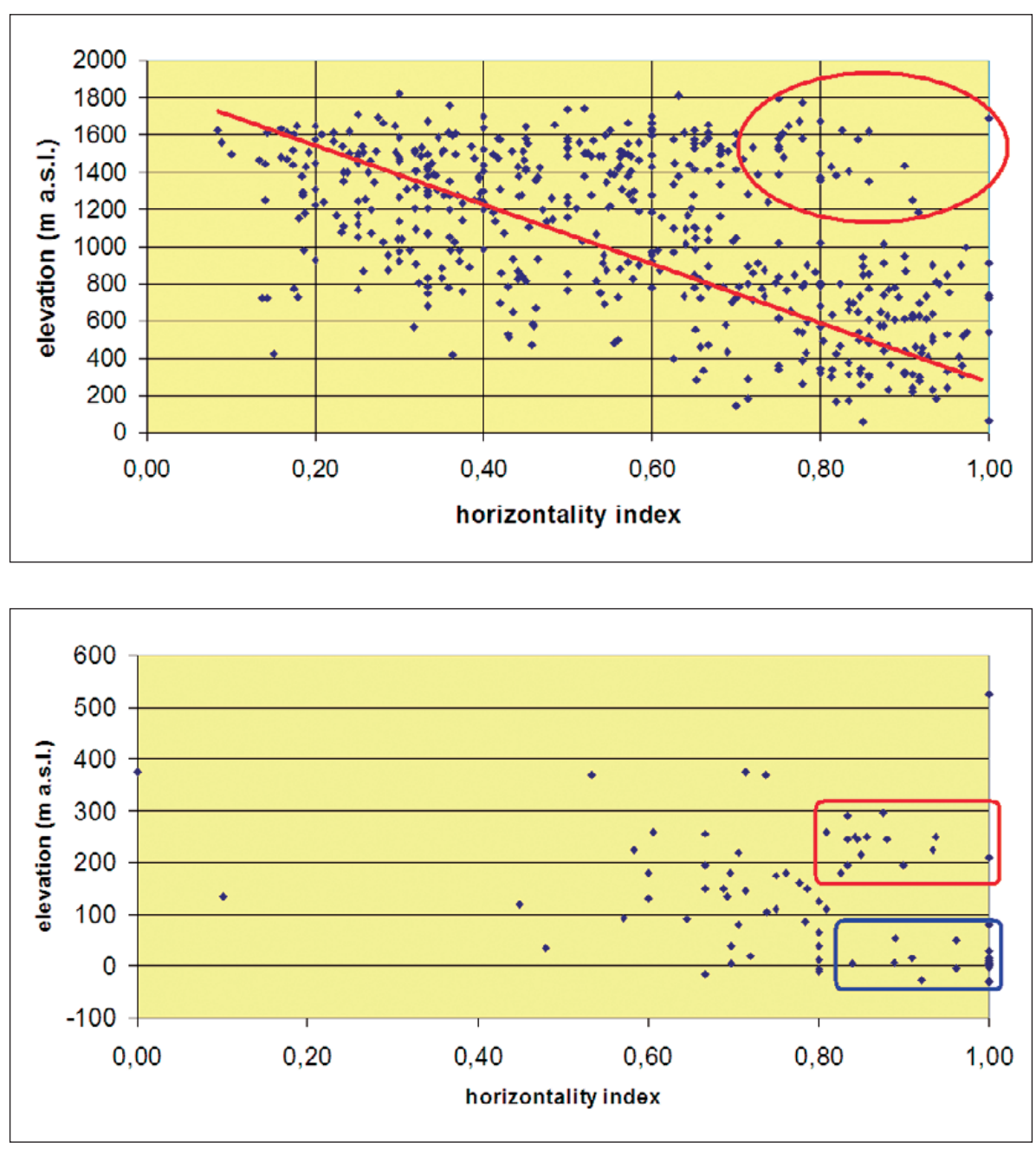

Fig. 7: Horizontality index (Hi) vs. altitude in the caves of the Alpi Apuane longer than $20 \mathrm{~m}$. The red circle indicates an old generation of relict horizontal caves diverging from the general negative trend (red line).

Fig. 8: Horizontality index $(\mathbf{H i})$ vs. altitude in the caves of Southern Tuscany coastal karst (surroundings of Grosseto, Tuscany). The red box indicates an old generation of coastal relict caves. The blue box indicates the recent generation of coastal caves around the present sea level (after: Iandelli \& Piccini 2006, modified).

Tab. 1: Summary of most significant morphometric indices obtained from cave dimensional parameters: row / line ratios. Authors: 1) Piccini 2001; 2) Klimchouk 2003; 3) Roth 2004; 4) Frumkin \& Fischlendler 2005.

\begin{tabular}{|c|c|c|c|c|c|c|c|c|c|}
\hline & $\begin{array}{c}\text { Plan } \\
\text { length }\end{array}$ & $\begin{array}{c}\text { Real } \\
\text { length }\end{array}$ & $\begin{array}{c}\text { Straight } \\
\text { length }\end{array}$ & $\begin{array}{c}\text { Straight } \\
\text { width }\end{array}$ & Perimeter & Area & $\begin{array}{l}\text { Cave } \\
\text { field }\end{array}$ & Volume & $\begin{array}{c}\text { Rock } \\
\text { volume }\end{array}$ \\
\hline Plan length & & & & & & 3 & & & \\
\hline Real length & 1 & & & & & & & & \\
\hline Straight length & 1 & & & & & & & & \\
\hline Straight width & & & 3,4 & & & & & & \\
\hline Perimeter & & & & & & 3 & & & \\
\hline Area & 3 & & & & & & & & \\
\hline Cave field & & & & & & $2,3,4$ & & & \\
\hline \multicolumn{10}{|l|}{ Volume } \\
\hline Rock volume & & & & & & & & 2 & \\
\hline
\end{tabular}

tuitous. Anyway, in the small-middle dimension caves with a high $\mathbf{H i}$, the elevation of the entrances is usually close to the mean elevation of the whole cave. This is not always true for large caves, whose high $\mathbf{H i}$ can be due to a deep level of horizontal passages. Despite this, one of the most significant analysis concerns the altimetric dis- tribution of small-medium caves with high horizontality index (Figs. 7 and 8), because it allows to recognize cave levels, marked by the occurrence of relict piezometric passages, at elevation above the present base level (Iandelli \& Piccini 2006). 


\section{CONCLUSION}

In the last years, the use of personal computer and the possibility to get digital surveys of caves have led many karst researchers to use morphometric indices to classify caves according to morphological and genetic models. This kind of approach is useful for preliminary investigation and to identify caves of particular interest. Many of these indices are reliable for simple caves, such as coastal caves (Mylroie \& Mylroie 2007) or isolated caves (Frumkin \& Fischhendler 2005) that have a little vertical range, whereas the analysis of large multi-phase systems requests the use of 3D models (Filipponi et al., 2009). All these morphometric analysis request a long work of digitizing of cave maps or the possibility to get a 3D model from survey data.

A more simple analytical approach, based only on the common dimensional parameters usually described in cave inventories, can be used to investigate a large population of caves.

The indices can be analyzed by cross correlation with other parameters, such as dimension or elevation, and can provide useful indications to recognize morphological types and different generations of caves.

\section{ACKNOWLEDGEMENTS}

I'm grateful to R. Curl and A. Klimchouk for their useful suggestions to this work.

\section{REFERENCES}

Coltorti, M., 1981: Geomorphological evolution of a karst-area subjected to neotectonic movements in the Umbria-Marche Apennines (Italy).- Proc. VIII Int. Congr. Speleol., Bowling-Green, Kentucky, 8488 , Kentucky.

Curl, R.L., 1964: On the definition of a cave.- National Speleological Society Bull., 26, 1-6.

Curl, R.L., 1966: Caves as a measure of karst.- Journal of Geology, 74, 798-830.

Curl, R.L., 1986: Fractal dimensions and geometries of caves.- Mathematical Geology, 18, 8, 765-783.

Deike, G. H., 1969: Relations of jointing to orientation of solution cavities of Central Pennsylvania.- American Journal of Science, 267, 1230-1248.

De Waele, J. \& L. Piccini, 2008: Speleogenesi e morfologia dei sistemi carsici in rocce carbonatiche.- In: Parise, M., Inguscio S. \& A. Marangella (eds.) Atti $45^{\circ} \mathrm{Cor}$ so CNSS-SSI "Geomorfologia carsica", Grottaglie, Bari, $2^{\text {nd }}-3^{\text {th }}$ February 2008, 23-74, Grottaglie.

Dreybrodt, W. \& J. Siemers, 2000: Cave evolution on two-dimensional networks of primary fractures in limestone.- In: Klimchouk, A. B., Ford, D. C., Palmer, A. N. \& W. Dreybrodt (eds.) Speleogenesis. Evolution of Karst Aquifers, Nat. Spel. Society, pp. 201-211, Huntsville, Alabama.
Eraso, A. \& N. Herrero, 1986: Propuesta de un Nuevo método de deducción de las direcciones principales de drenaje en el karst.- pp. 93, Jumar, Madrid.

Ewans, I.S., 1972: General geomorphometry, derivatives of altitude and descriptive statistics.- In: Chorley, R.J. (ed.) Spatial Analysis in Geomorphology, pp. 17-90, London, Methuen.

Filipponi, M., Jeannin, P.Y. \& L. Tacher, 2009: Evidence of inception horizons in karst conduit networks.Geomorphology, 106, 86-99.

Finnesand, T. \& R.L. Curl, 2009: Morphology of Tjoarvekrajgge, the longest cave of Scandinavia.- In: White, W.B. (ed.) Proc. 15th International Congress of Speleology, Kerville, Texas, $19^{\text {th }}-26^{\text {th }}$ July 2009 , 2, 878883, Kerville.

Ford, D.C. \& P. Williams, 2007: Karst Hydrogeology and Geomorphology.- John Wiley \& Sons Ltd, pp. 562, Chichester.

Frumkin, A. \& I. Fischhendler, 2005: Morphometry and distribution of isolated caves as a guide for phreatic and confined paleohydrological conditions.- Geomorphology, 67, 457-471.

Häuselmann, P., Jeannin, P.Y. \& T. Bitterli, 1999: Relationships between karst and tectonics: case-study of the cave system North of Lake Thun (Bern, Switzerland).- Geodinamica Acta, 12, 6, 377-387. 
Haüselmann, P., Jeannin, P.-Y. \& M. Monbaron, 2003: Role of epiphreatic flow and soutirages in conduit morphogenesis: the Bärenschacht example (BE, Switzerland).- Zeitschrift für Geomorphologie 47, 171-190.

Klimchouk, A.B., 2003: Cave morphometry.- In: Gunn, J. (ed.) Encyclopedia of cave and karst science, Fitzroy Dearborn, pp. 1120-1125, New York.

Klimchouk, A.B. \& D.C. Ford, 2000: Lithologic and structural controls of dissolutional cave development.- In: Klimchouk, A.B., Ford, D.C., Palmer, A.N. \& W. Dreybrodt (eds.) Speleogenesis. Evolution of Karst Aquifers, Nat. Spel. Society, pp. 54-64, Huntsville, Alabama.

Klimchouk, A.B., 2007: Hypogene speleogenesis: hydrogeological and morphogenetic perspective.- National Cave and Karst Research Institute, Special Paper, pp. 106, Carlsbad, USA.

Iandelli, N. \& L. Piccini, 2006: Rapporti tra morfogenesi carsica ed evoluzione paleogeografica nelle aree costiere della Toscana Meridionale.- Il Quaternario, Italian Journal of Quaternary Science, 19, 1, 79-87.

Lowe, D. J., 2000: Role of stratigraphic element in speleogenesis: the speleoinception concept.- In: Klimchouk, A. B., Ford, D. C., Palmer, A. N. \& W. Dreybrodt (eds) Speleogenesis. Evolution of Karst Aquifers, Nat. Spel. Society, pp. 65-76, Huntsville, Alabama.

Mylroie, J.E. \& J.L. Carew, 1990: The flank margin model for dissolution cave development in carbonate platforms.- Earth Surface Processes and Landforms, 15, 413-424.

Mylroie, J.R. \& J.E. Mylroie, 2007: Development of the carbonate island karst model.- Journal of Cave and Karst Studies, 69, 59-75.

Ohmori, H., 1993: Changes in the hypsometric curve through mountain buildings resulting from concurrent tectonics and denudation.- Geomorphology, 8, 263-277.

Palmer, A.N., 1987: Cave levels and their interpretation.National Speleological Society Bull., 49, 50-66.

Palmer, A.N., 1991: Origin and morphology of limestone caves.- Geological Society of America Bull., 103, $1-21$.
Piccini, L., 1992: Rapporti tra andamento dei reticoli carsici e superfici di discontinuità nelle formazioni calcaree delle Alpi Apuane.- Atti Conv. Ricerca e protezione delle risorse idriche sotterranee delle aree montuose, Ottobre 1992, Quaderni ASM, 43, 37-53, Brescia.

Piccini, L., 1994: Caratteri morfologici ed evoluzione dei fenomeni carsici profondi nelle Alpi Apuane (Toscana - Italia).- Natura Bresciana, 30, 45-85.

Piccini, L., 1998: Evolution of karst in the Alpi Apuane (Italy): Relationships with the morphotectonic history.- Suppl. Geografia Fisica e Dinamica Quaternaria, 3, 4, 21-31.

Piccini, L. 2001: L'Analisi morfometrica delle grotte carsiche.- Atti $18^{\circ}$ Congr. Nazionale Speleologia, 145-149.

Plan, L., Filipponi, M., Behm, M., Seebacher, R. \& P. Jeutter, 2009: Constraints on alpine speleogenesis from cave morphology - A case study from the eastern Totes Gebirge (Northern Calcareous Alps, Austria).- Geomorphology, 106, 118-129.

Roth, M.J., 2004: Inventory and geometric analysis of flank margin caves of the Bahamas. MsS. Thesis, Mississippi State University, pp. 117.

Roth, M.J., Mylroie, J.E., Mylroie, J.R., Ersek, V., Ersek, C.C. \& J.L. Carew, 2006: Flank Margin Cave Inventory of the Bahamas.- In Davis, R.L. \& D.W. Gamble (eds.) Proc. $12^{\text {th }}$ Symposium on the Geology of the Bahamas and Other Carbonate Regions, 153-161, San Salvador, Bahamas.

Strahler, A.N., 1952: Hypsometric (area-altitude) analysis of erosional topology.- Geological Society of America Bull., 63, 11, 1117-1142.

Strahler, A.N., 1957: Quantitative analysis of watershed geomorphology.- Transactions of the American Geophysical Journal, 8, 6, 913-920.

White, W. B., 1988: Geomorphology and Hydrology of karst terrains.- Oxford University Press, pp. 464, New York.

Williams, P.W., 1982: Speleothem dates, Quaternary terraces and uplift rates in New Zealand.- Nature, 298, 257-260. 